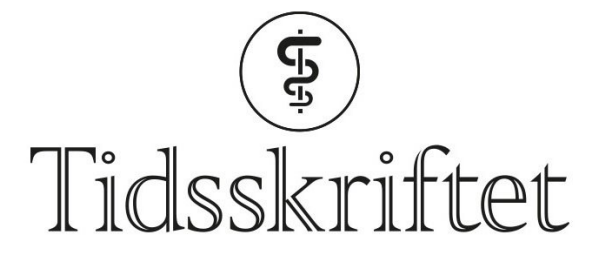

DEN NORSKE LEGEFORENING

\title{
Forside nr. 15/2019
}

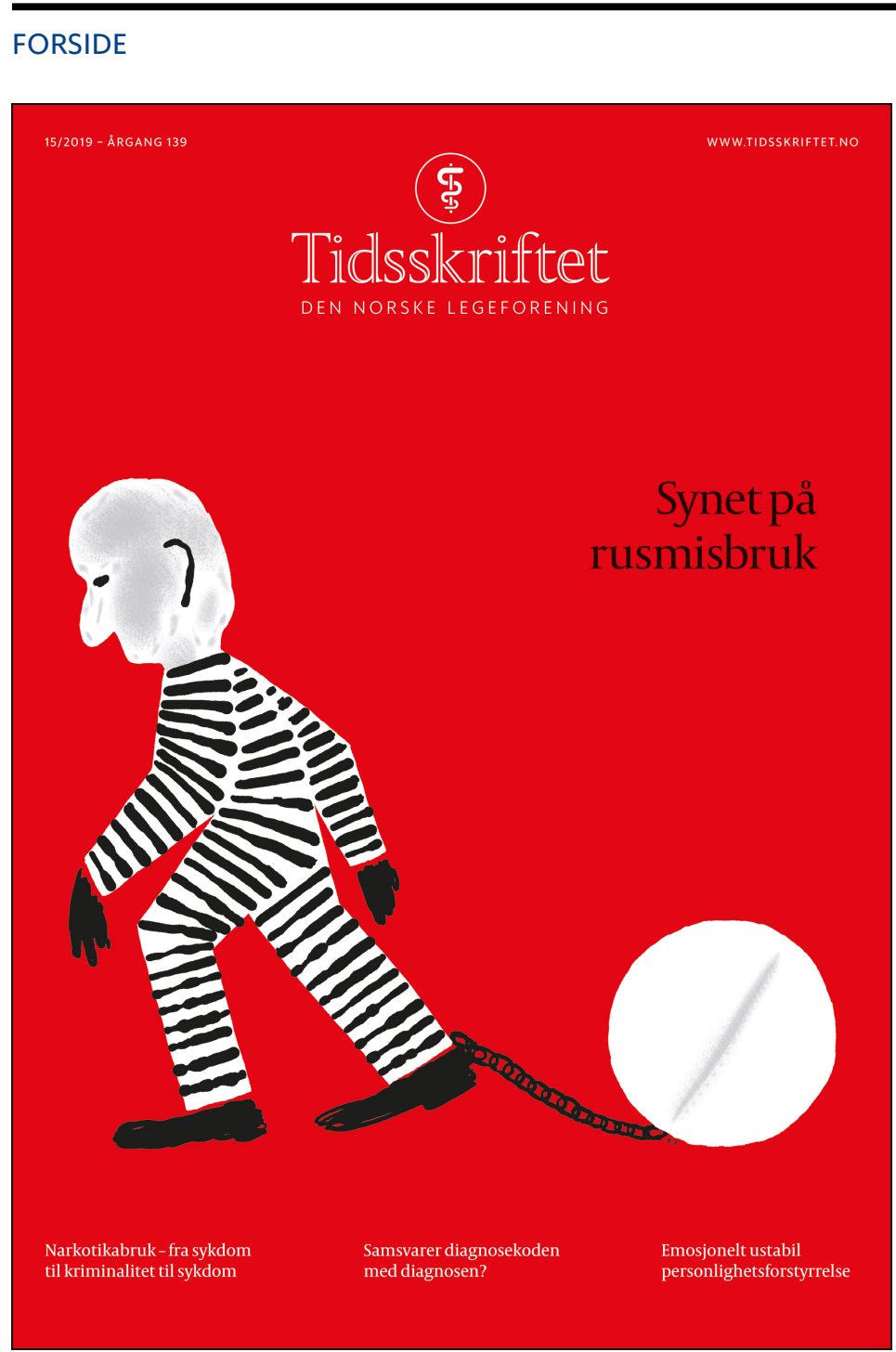

Illustrasjon (C) Espen Friberg

Pasient eller kriminell? I dette nummeret har vi en artikkel om hvordan «narkotikaproblemet» har blitt oppfattet gjennom tidene - fra helseproblem til samfunnsproblem og tilbake igjen. I 2004 fikk rusavhengige pasientrettigheter, men det er nok et stykke igjen $f ø r$ vi har et likeverdig helsetilbud til denne pasientgruppen, spesielt i fengslene. Norge ble i 2014 første land i verden med rus- og avhengighetsmedisin som egen helspesialitet, en tverrfaglig spesialitet som reflekterer de sammensatte problemene rusavhengige kan ha. Forsideillustrasjonen til dette nummeret er laget av Espen Friberg. Mer av hans kunst finner du her: www.espenfriberg.com 
Publisert: 21. oktober 2019. Tidsskr Nor Legeforen. DOI: 10.4045/tidsskr.19.15.02 (C) Tidsskrift for Den norske legeforening 2020. Lastet ned fra tidsskriftet.no 